\title{
The impact of channel integration on consumers' channel preferences: Do showrooming and webrooming behaviors matter?
}

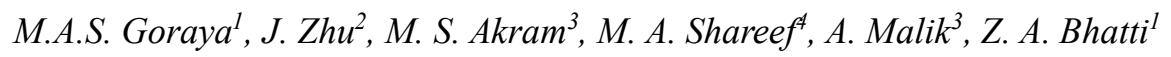

\begin{abstract}
This study investigates the relationships among channel integration and consumers' online and offline patronage intentions. The theoretical framework proposes perceived empowerment, perceived assortment, and perceived benefits as mediating variables in the channel integrationpatronage intention relationship, with consumer showrooming and webrooming behaviors as moderating variables. Data was collected by means of two studies; that is, for search and for experience products, respectively. The proposed conceptual model was tested by employing variance-based structural equation modeling. The results of both studies confirm that channel integration significantly affects consumers' channel preferences. The mediating roles of empowerment, assortment, and benefits were confirmed for all of the relationships except for the mediating effect of empowerment on the relationship between channel integration and offline patronage intention. Further, showrooming and webrooming moderated the positive impact of channel integration on online/offline patronage intentions. The study contributes to the multi-channel retailing literature by providing useful implications for academicians and practitioners.
\end{abstract}

Keywords: Channel integration, empowerment, assortment, benefits, showrooming, webrooming, patronage intentions

${ }^{1}$ Portsmouth Business School, University of Portsmouth, Portsmouth, UK

${ }^{2}$ School of Business Administration, Southwestern University of Finance and Economics, China

${ }^{3}$ Essex Business School, University of Essex, Colchester, United Kingdom

${ }^{4}$ School of Business \& Economics, North South University, Bangladesh 


\section{$1 \quad$ Introduction}

The integration of retailers' shopping channels aimed at creating a cohesive and seamless shopping experience for consumers is a concept driven by omni-channel retailing (Cummins et al., 2016). It is very rare in omni-channel retailing that consumers shop solely via physical or online stores; instead, they may opt to shop through integrated channels. Doing so not only facilitates the gathering of information but also provides consumers with the autonomy to exercise their cross-channel free-riding behavior. The liberty to gather information and to execute their cross-channel free-riding behavior empowers consumers to augment their shopping choices (Bang et al., 2013). Although the integrated channel-retailing model is becoming a trend among new age retailers, the patronage it creates among consumers is still not fully explicated. A survey by IKEA (UK) noted that making products accessible at online and offline retailing channels can compel consumers to shop from both channels; it also increased their online sales by $31 \%$ (Lee et al., 2019). Similar to Lee et al. (2019), International Data Corporation (IDC) projected that consumers who opt to use both offline and online stores would experience $30 \%$ higher lifetime value than those purchasing from a single channel (Krueger, 2015).

While the extant academic literature address varied consumer understanding of attaining a unified and seamless shopping experience over integrated channels, several other studies offer insights about consumers' cross-channel free-riding behavior. One study in the United States portrayed that $26 \%$ of consumers have practiced showrooming by using mobile devices and social media (Shi and Liu, 2018). Flavián et al. (2016) and Berthiaume (2019) depicted that in the United States and United Kingdom 57\% of consumer electronics (i.e., laptops/tablets and mobile phones) and 54\% of apparel purchases (clothing and shoes) were bought on the basis of showrooming behavior. In contrast, $41 \%$ of U.S. consumers opted for webrooming, while $35 \%$ of European consumers exercised webrooming only for electronic items and $48 \%$ of consumers used webrooming for apparel.

While the academic literature presents varied insights into integrated channels, our study suggests that consumer considerations, such as empowerment, assortment and benefits, remain a matter for further in-depth investigation in the context of diverse patronage over integrated channels. The creation of consumer empowerment is a broader academic subject that has its insights in the fields of economics and social sciences (Heitz-Spahn, 2013). It denotes the degree to which consumers control their shopping iterations over integrated channels (HeitzSpahn, 2013; Zhang et al., 2018). While consumers gain control over their choices and become more empowered, they concurrently look for other benefits from integrated channels. In the 
consumer marketing domain, benefits are the positive values that a product or service conveys in shaping the goal-directed behavior of consumers (Zhu et al., 2018). In general, the accepted practice for marketers is to prioritize consumer benefits because benefits drive more desired consumer behavioral reactions. However, by enhancing the adaptability of integrated channels, the consumer can gain a lot of relative and absolute benefits, such as effectiveness, efficiency, availability of products, accessibility from anywhere, comfort in use, time savings, cost savings, usefulness, and convenience (Zhu et al., 2018).

Although perceived empowerment and benefits stimulate consumers to shop over integrated channels, the product assortment structure is also vital in the choice of a retailer (Gensler et al., 2017; Verhoef et al., 2015). Product assortments are determined by their related use with other products offered by retailers. Consumers perceive assortment items from the perspective of their similarity and their compatibility with their end use (Melis et al., 2015). Although obtaining insights about empowerment, product categorization with related assortment structures, and benefit considerations is the motivation of this study, understanding how they facilitate consumers' channel switching behavior will also allow us to propose new insights. For academic insights, channel-switching behaviors are termed as showrooming (visiting physical stores for products and then buying them from an online store) and webrooming (visiting an online store for products and then buying them at a physical store) (Li et al., 2018). The extant literature has recognized diverse mechanisms that dictate the impact of channel integration on patronage intention (Baal, 2014); however, the current research setting is fragmented in terms of the product choices of experience and search. For these reasons, we advance a consolidated theoretical framework that synthesizes and empirically corroborates the mediating and moderating influences of latent constructs such as showrooming, webrooming, empowerment, benefits, and assortments on the relationship between channel integration and consumer patronage intentions. This research addresses the above-mentioned consumer/retailer concerns with an online survey approach to create new academic and managerial implications.

To envision the merits of integrated channels based on different product characteristics, this study offers potential academic and contextual contributions. First, it shows the role of integrated channels in specifying the patronage intention among users. Certain past studies have offered understanding of patronage intentions over integrated channels (Emrich et al., 2015; Zhang et al., 2018), but to the best of our knowledge, no such study exists that presents its findings in the context of bifurcated patronage intention - that is, online and offline. Second, when considering the desired shopping needs of consumers over integrated channels, the roles 
of perceived empowerment, perceived assortment, and perceived benefits are taken as intervening constructs between channel integration and patronage intentions (online and offline) to exhibit novel outcomes. Third, this study explicitly offers the moderating role of showrooming and webrooming in the relationship between channel integration and patronage intentions (online and offline) to understand consumers' cross-channel free-riding behavior amid different product types. Fourth, the validated theoretical framework used herein provides extended actionable insights to practitioners, particularly on emerging markets, for strategizing how to improve channel integration. In particular, this study investigates the following research questions: (1) How does channel integration affect consumer patronage intentions of (a) online stores and (b) offline stores? (2) How do perceived empowerment, perceived assortment, and perceived benefits mediate the relationships between channel integration and consumers' channel preferences for (a) online stores and (b) offline stores? (3) How do consumers' channel switching behaviors (i.e., showrooming and webrooming) moderate the relationship between channel integration and consumer patronage intentions for (a) online stores and (b) offline stores?

The rest of the paper is structured as follows: sections 2 and 3 present theoretical foundations and hypotheses formulation along with the conceptual framework; Sections 4 and 5 elaborate upon the research methodology and results; and section 6 offers discussions and conclusions along with theoretical and managerial implications.

\section{Theoretical foundations}

\section{$2.1 \quad$ Channel integration}

The literature presents insights on consumer behavior with thoughtful findings on channel integration and patronage intentions (Emrich et al., 2015; Gensler et al., 2017; Hossain et al., 2019; Zhang et al., 2018). Online and offline channel integration is different from the multichannel perspective in that it personifies its value and delivery mechanism, thereby helping retailers to assist consumers (Baal, 2014; Emrich et al., 2015; Herhausen et al., 2015). In regard to the omni-channel, the extant literature explicitly advocates that the significance of channel integration resides in the realization of the benefits it offers, which include collateral channel sales growth and augmented consumer experiences (Cao and Li, 2015; Verhoef et al., 2015). Based on an in-depth appreciation of consumers concerning integrated channels, six of the top fifteen Internet retail companies in France are now multi-channelled, and 4.3 million French consumers have purchased their products from either integrated channels or multichannel retailers after experiencing various channel shopping benefits (Fevad, 2017). Even in Asian markets, this approach has been adopted by many retailers. Alibaba's (a popular China- 
based shopping platform) strategic investment of Suning and Jingdong (JD) with Yonghui and Walmart has shown the importance of integrated channels for practitioners (Zhu et al., 2018). Consumers appreciate the dynamics of integrated channels and the patronage it creates, while they simultaneously gain knowledge of different product characteristics by using integrated channels. In order to gain adequate knowledge for a productive shopping experience, consumers browse both online and offline channels (Flavián et al., 2016). In current times, consumers who benefit from an information gathering facility over integrated channels typically use a buy online and pick up in-store (BOPS) strategy that results in additional store sales and also adheres to cross-selling mechanisms (Gallino and Moreno, 2014). However, the literature also predicts that the BOPS strategy is not appropriate for products which have good sales at the store (Gao and $\mathrm{Su}, 2017)$. Gao and $\mathrm{Su}$ (2017) also argued that BOPS helps in reaching new customers but may lead to less sales and less effectiveness with existing customers, and in a decentralized retail system, BOPS revenue may further be distributed among channels to sustain decentralized channel efficiency. At points where the literature provides varied insights, researchers believe that retailer attractiveness from the perspective of channel integration is crucial for consumer retention (Gensler et al., 2017; Melis et al., 2015). However, many studies show converging evidence and portray that online-offline integration leads to a competitive advantage and promotes channel synergies instead of retailers' channel cannibalization (Herhausen et al., 2015; Ofek et al., 2011; Tagashira and Minami, 2019).

\section{$2.2 \quad$ Webrooming and showrooming}

The concepts of webrooming and showrooming used in this study are similar to the ones used in past research (Flavián et al., 2019; Kang, 2018). In showrooming, a consumer first looks for products in the physical store and then opts to shop online, whereas in webrooming a consumer first browses the online store (for products) and chooses to shop at the physical store (Flavián et al., 2016; Gensler et al., 2017; Heitz-Spahn, 2013). Existing literature acknowledges that the Internet now stands as the consumer's preferred means of information gathering whereas physical stores stand as the main purchasing channel (Fernández et al., 2018; Yadav et al., 2014). During the shopping decision process, consumers evaluate the costs and benefits of multi-channels, choose a combination of channels that minimize their shopping reservations, such as the cost of time, effort, money, and risk, and maximize their shopping gains, such as the right purchases and better deals (Gensler et al., 2017; Pauwels and Neslin, 2015).

Even though past studies have discussed the mechanisms to retain consumers (Shareef et al., 2019), retailers still believe that consumers' cross-channel free-riding behavior needs to be further addressed, because consumers perceive uncertainties over online/offline channels for 
varied product characteristics (Heitz-Spahn, 2013). While the online channel provides more information-gathering tools to assist consumer decision making, redundant information limits their cognitive abilities and sparks feelings of confusion and anxiety, which adds up to uncertainty. Similarly, the offline channel, which lacks an information search and product/price comparison, also creates consumer anxiety and confusion ( $\mathrm{Li}$ et al., 2018). To address such uncertainties, retailer integration of online and offline channels aids consumers from the perspective of webrooming and showrooming. As different products carry have different characteristic, the showrooming and webrooming mechanisms help consumers choose products more efficiently (Wolny and Charoensuksai, 2014; Zhu et al., 2018). Showrooming and webrooming mechanisms can address consumers' various shopping considerations, such as tangibility, consciousness, information access, choice confidence, and search-process satisfaction (Reid et al., 2016).

While the past literature has argued about various shopping considerations, it has also observed the impact of channel synergies on consumer behavior. Gensler et al. (2012) presented channel attributes, such as convenience and risk, experiential effects, and the spillover effects, during the complete purchase process. Their study found that convenience is vital during the purchasing and after-sales process, clarifying that channels complement each other and create an inclination among consumers to use channel integration. Singh et al. (2014) proposed a model for information gathering prior to the purchase of durable products and argued that using an online store actually complements shopping at a physical store. Similarly, other literature insights have solicited that shopping from cross-channels is positively related to high consumption, inclination toward integrated retailers, satisfaction, and loyalty (Flavián et al., 2016; Melis et al., 2015). Gensler et al. (2017) unfolded the motives behind showrooming, such as comparison of product quality, price, and different costs across channels. Similarly, Rapp et al. (2015) justified the effects of showrooming on consumers' efficiency and performance. Herhausen et al. (2015) further advocated that showrooming supports a rich consumer experience under an integrated channel format.

Although previous studies have presented varied insights about showrooming and webrooming and their impacts on consumer behaviors, the insights on consumers' bifurcated patronage intentions (online and offline) are still scant. Hence, this study examines the moderated effects of showrooming and webrooming on the pathways of channel integration and consumers' bifurcated patronage and thereby extends the existing literature. 


\subsection{Empowerment, assortment, and benefits}

Literature suggests that retailers can leverage a coherent and reputable image of integrated channels by addressing consumer psychological needs, such as empowerment, underlined channel integration benefits, and complex assortment structures (Bertrandie and Zielke, 2017; Heitz-Spahn, 2013; Li et al., 2018). Retailing businesses today are depicting changes that are very often due to various consumer perceptions and needs, and consumers have regained control from sellers of their decision making, which relates to the concept of consumer empowerment. From the classical economic theory literature, consumer empowerment denotes the capability of consumers to take control of their choices (Wathieu et al., 2002). Consumer empowerment addresses essential insights into the channel integration phenomenon, which leads consumers to ascertain their patronage through trust and satisfaction (Heitz-Spahn, 2013; Zhang et al., 2018).

In past literature, the empowerment concept has carried a variety of connotations. Some studies proposed it as giving authority to someone to control or manage other people (Cattaneo and Chapman, 2010). However, few studies have provided their findings from the perspective of providing liberty to someone in doing things in their desired way (Wathieu et al., 2002). Some studies describe consumer empowerment as providing strength to consumers through enabling more avenues for information gathering, choice freedom, or by providing more control of decision making (Wathieu et al., 2002). From the perspective of online shopping, consumers gain more resources as decision-aids, which helps them in gaining more control (Broniarczyk and Griffin, 2014). In discussions on empowerment, Li et al. (2017) provided their insights into the dimensions of emotional and cognitive perspectives. Similarly, Shankar et al. (2006) argued that consumer empowerment includes providing knowledge and information to consumers through which they exercise the autonomy of choice selection. Moreover, Hu et al. (2019) argued that empowering consumers through more information gathering avenues does not always reduce decision difficulty; however, it remains indistinct as to which information actually hampers the consumer decision process.

While some recent literature in the consumer marketing domain has provided insights on consumer self-control, scholars have also addressed the importance of perceived benefits and product assortment structure in shaping consumer patronage intentions over integrated channels (Emrich et al., 2015). Benefits are the positive values that a product or service conveys in shaping the right goal-directed behavior among consumers. The accepted practice for marketers is to prioritize consumer benefits because benefits, in general, drive more behavioral or emotional reactions. In the channel integration literature, consumer benefits are mainly 
composed of perceived variety, perceived convenience, and perceived risk, which capture the gains from retailers over integrated channels to determine consumer patronage (Emrich et al., 2015; Zhang et al., 2018). This explanation expands the limited concept of the theory of reasoned action (Esposito et al., 2016) and captures only the absolute benefits of channel integration. However, by enhancing the adaptability of an integrated channel, consumers can gain both relative and absolute benefits, including effectiveness, efficiency, availability of products, accessibility from anywhere, comfort in use, time savings, cost savings, usefulness, and convenience (Arora and Sahney, 2018).

The concept of dispensing benefits over an integrated channel is important from economic, organizational, marketing, and behavioral perspectives. By considering a transaction cost analysis, we can better understand that integrated channel benefits capture the spirit of time and price savings (Emrich et al., 2015; Gensler et al., 2017; Zhu et al., 2018). Several studies have also suggested that the time constraint is of great importance in today's fast-moving world where consumers are most concerned about time, convenience, information gathering, and ease of use when shopping for specific products over integrated channels (Gensler et al., 2017). The related literature exemplifies consumer cross-channel behaviors by considering empowerment, product assortment structures, and shopping benefits over integrated channels, which are preconditions for retailers to embrace a channel integration mechanism. This study incorporates these variables as the intervening constructs between channel integration and consumers' bifurcated patronage intentions to understand consumers' channel preferences.

\section{Hypotheses development}

\subsection{Channel integration and patronage intention (online and offline)}

On an integrated channel framework, consumer activities are synchronized across certain areas of shopping interest, such as promotions, transactions over integrated channels, pricing and product information, order fulfillment, and customer service (Oh et al., 2012). Nowadays, consumers opt for different strategies amid retailers' channel integration to show their patronage, such as BOPS, which provides extended store sales and also supports cross-selling mechanisms (Gallino and Moreno, 2014). Based on consumer shopping patterns over integrated channels, the existing literature has investigated the effect of online-offline channel integration from different perspectives (Zhang et al., 2018). Bendoly et al. (2005) presumed that the risk perceived by consumers of the non-availability of a product is minimized through the self-service information portals provided in the offline store, which offer the possibility for consumers to use both online and offline channels (Wolny and Charoensuksai, 2014). Similarly, the findings of Patrício et al. (2008) on the banking sector showed that consumers perceived a 
better environment and service upon interacting with the online terminals provided in banks, hence keeping a balance among information symmetry on both channels. Likewise, Glushko and Tabas (2009) reported that employees of firms provided better and updated customer service upon interacting with the provided online terminals, thus personifying the importance of online-offline channel integration to consumers. Conversely, from the perspective of offlineonline integration, retailers provide physical store information on their websites, such as store hours, product assortment structures, store locations, and integrated discount and promotional information. Such information enhances consumers' perceived benefits and patronage intention regarding the online stores (Herhausen et al., 2015).

Based on insights from the literature on integrated channels, consumers will patronize stores due to the collateral benefits of both online and offline channels (Zhang et al., 2018). Moreover, patronage in an integrated retailing context denotes the relationship between retailers and consumers based on the synergies dispensed over different channels. Particularly in retailing, the concept of patronage is categorized by the trade-off between the retailer and consumer, whereby the retailer bestows its services amidst consumer shopping considerations (Blut et al., 2018). Built on the synergies created over an integrated channels framework, consumers exercise their positive shopping attitude toward retailers' online/offline shopping channels (Emrich et al., 2015; Shareef et al., 2018). Studies have argued that the patronage intentions of consumers are subject to the various benefits offered over integrated channels. Moreover, the structure of channel integration also plays an integral role in consumers' patronizing shopping intents. Hence, based on the above discussions, we propose the first hypothesis as follows:

H1: Channel integration positively influences consumer patronage intention for (a) online stores and (b) offline stores.

\subsection{Mediation (empowerment, assortment, and benefits)}

Consumers have currently regained control of their decision making from sellers. Generally, contemporary retailers are more concerned with providing consumers additional ways of gathering information based on product categorization so as to ascertain their buying patronage. A significant component of consumer empowerment resides in the creation of the ability for consumers to control their choices (Wathieu et al., 2002). Channel integration offers consumers a self-controlled and unified shopping practice. First, it presents more choices to consumers, such as the choice of a suitable channel based on product characteristics and shopping needs. Arora and Sahney (2018) argued that by considering consumer traits of cross-channel free riding, the convenience of using an online channel, and the desire to address tangibility consciousness at an offline store, the integration of channels thus helps retailers to provide a 
self-control mechanism to consumers. Similarly Li et al. (2018) and Zhang et al. (2018) suggested that empowering and providing self-control to consumers results in satisfaction among consumers, which positively influences their patronage. Second, the integrated communication mechanism over different channels helps consumers to address their uncertainty and confusion (Broniarczyk and Griffin, 2014). Such mechanisms aid consumers in procuring product knowledge, which in turn complements their shopping exercise.

While consumers gain control over their choices and become more empowered, they concurrently see other benefits of integrated channels. By enhancing the adaptability of an integrated channel, a consumer can gain many relative and absolute benefits ranging from effectiveness, efficiency, availability of products, accessibility from anywhere, comfort, time and cost savings, usefulness, and convenience (Baal, 2014; Emrich et al., 2015). Kacen et al. (2013) suggested that the combined effects of relative and absolute benefits capture the essence of absolute and comparable benefits in an integrated channel infrastructure. Hence, the concept of dispensing benefits over an integrated channel has economic, organizational, marketing, and behavioral importance.

Although perceived empowerment and benefits are considered as factors in shopping over integrated channels, product assortment structure also stands as a vital determinant for consumers' channel and retailer choices (Gensler et al., 2017; Verhoef et al., 2015). Rubio et al. (2017) noted that product assortments are determined by their related use to other products offered by retailers. Consumers perceive assortment items from the perspective of their similarity and compatibility with their end-use. Assortment has different types of relationships with products, such as substitutive, complementary, and independent (Emrich et al., 2015). Emrich et al. (2015) presented that a substitutive relationship addresses the same consumer needs but serves as an alternative in one choice; a complementary relationship depicts a higher consumption utility of the selected product from the joint use of assortment with the product; and independent relationship denotes that the assortment has no relationship with the product and that the choice of buying such assortment does not influence product use. In an integrated channel in which retailers spur consumer motivation to shop through both online and offline channels, the assortment structure also plays an integral role (Kang, 2018; Melis et al., 2015). Kahn and Wansink (2004) argued that consumers' perception of assortment and its choice differ based on its usage, and the impact of assortment structures over integrated channels varies due to the assortment of relationships. Hence, based on the above discussions concerning empowerment, product assortment, and benefits, we hypothesize the following.

H2: Perceived empowerment mediates between the relationship of channel integration and 
consumer patronage intention for (a) online stores and (b) offline stores.

H3: Perceived assortment mediates between the relationship of channel integration and consumer patronage intention for (a) online stores and (b) offline stores.

H4: Perceived benefits mediate between the relationship of channel integration and consumer patronage intention for (a) online stores and (b) offline stores.

\subsection{Moderation (showrooming and webrooming)}

The recent technological shift in the retailing world has introduced the concept of integrated channel formats while considering consumer cross-channel free-riding behavior (Arora and Sahney, 2018). Past studies have suggested that shopping in integrated channels requires highly involved behavior (Neslin, 2009). Showrooming and webrooming mechanisms help consumers to more efficiently choose products with varied characteristics (Zhu et al., 2018). Showrooming and webrooming mechanisms address various consumer shopping considerations, such as tangibility consciousness, information access, choice confidence, and search-process satisfaction.

Showrooming and webrooming have recently sparked widespread interest in the retailing industry. Although the concept is not new to practitioners, it still carries considerable relevance to the cross-channel free-riding behavior of consumers, consumer search patterns for certain products, their hybrid shopping intentions, and integrated channel shopping considerations (Baal and Dach, 2005; Gensler et al., 2017; Neslin, 2009; Schröder and Zaharia, 2008; Wang et al., 2015). Consumers' concerns about tangibility and quality for high-priced items lead them to engage in webrooming behaviors. However, price- and product-comparison sensitive consumers like to browse the online channels and then opt to utilize the showroom. Studies in the integrated channel and multichannel retailing framework confirm that consumers use different channels during a single purchase process to maximize their shopping benefits (Frasquet et al., 2015; Gensler et al., 2017; Neslin, 2009; Verhoef et al., 2015). Hence, based on the above discussions, we propose the following hypotheses:

H5a: Showrooming moderates the relationship of channel integration and consumer patronage intention for an online store.

H5b: Webrooming moderates the relationship of channel integration and consumer patronage intention for an offline store. 


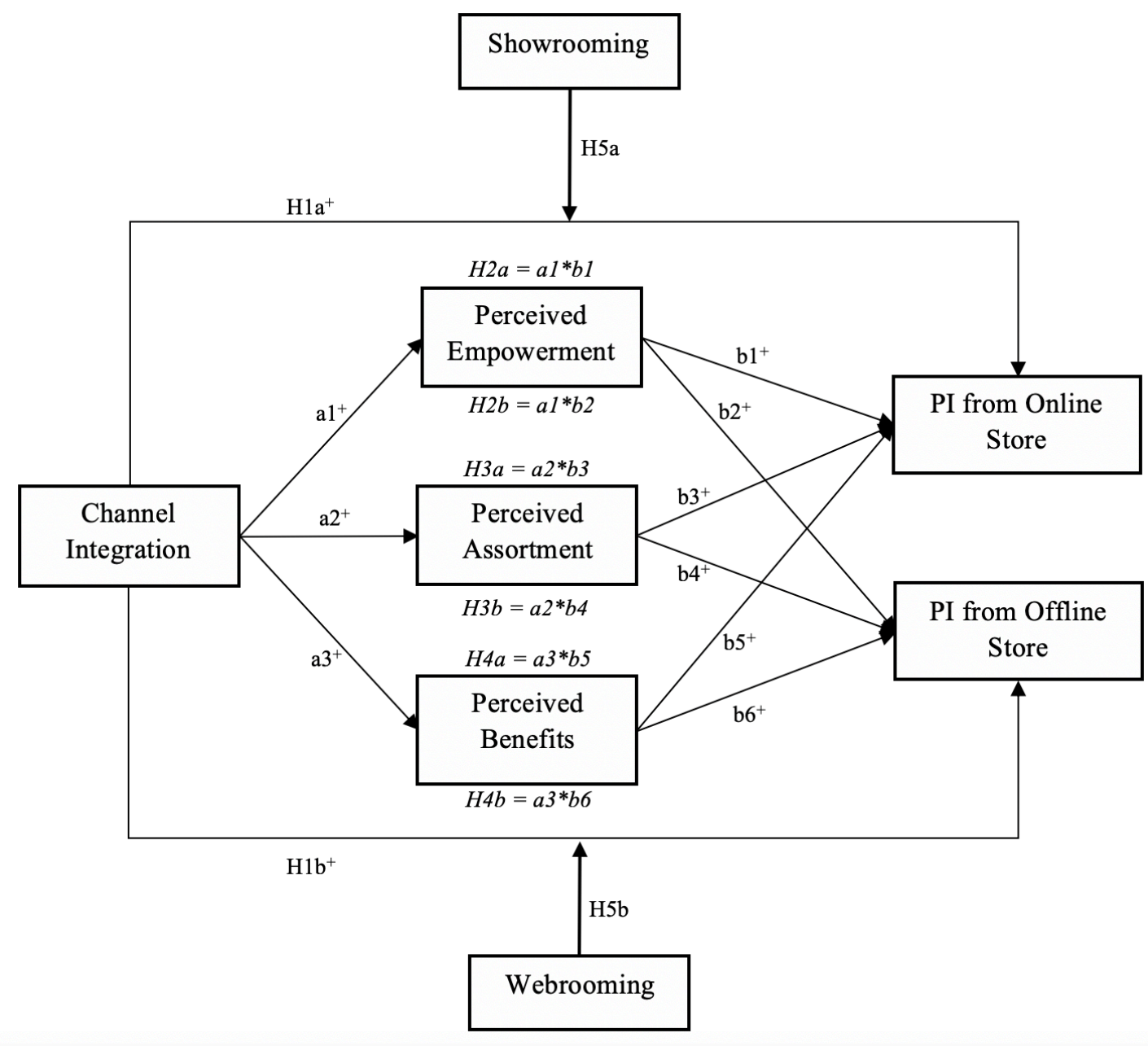

Figure 1 Conceptual framework

\section{$4 \quad$ Method}

We conducted two separate online studies (study 1 and study 2) through www.wjx.cn (an online data collection web portal) to measure consumer patronage intentions based on their channel switching behavior and other shopping considerations. In study 1, consumers were invited to provide their responses in an online survey while considering the purchase of search products such as electronics. Similarly, in study 2, consumers were invited to register their responses in an online survey while considering the purchase of experience products such as clothing. Our study considered apparel as an experience product and mobiles, tablets, and laptops as search products (Zhu et al., 2018). As both studies were intended to envision the merits of integrated channels based on different product characteristics, potential respondents were presented with the definition of an integrated channel. Additionally, to abstain from any confounding responses, the respondents were also presented with existing well-established 
integrated channel businesses as examples. Furthermore, at the start of the questionnaire, respondents were asked: "Have you ever purchased from an integrated channel of the retailer?" Only respondents with purchasing experience from an integrated channel were allowed to continue the survey after entering the retailer's name.

\subsection{Scale development}

A brief introduction to the research project was provided at the beginning of a structured questionnaire along with the definitions of the latent variables that were used. To measure each latent variable, we adapted multi-item scales from prior and similar channel integration research. The scales to measure channel integration and perceived empowerment were adapted from Zhang et al. (2018); perceived assortment was adapted from Kahn and Wansink (2004) and Emrich et al. (2015); perceived benefits were adapted from Shareef et al. (2011); showrooming and webrooming were adapted from Rapp et al. (2015); and, lastly, online and offline patronage intentions were adapted from Emrich et al. (2015). We employed a 7-point Likert scale for all items (except demographics); all constructs and their measurement items are provided in Appendix-1. Initially, the questionnaire was designed in English, which was then translated into Chinese for respondents' understanding. We used the translation and backtranslation methodology to certify linguistic uniformity. The survey was reviewed for content validity by faculty members and doctoral students researching consumer behavior. The feedback of faculty members and doctoral students led to a concise and final version of the survey.

\subsection{Sample characteristics}

After eliminating non-pertinent responses for both studies based on survey response time (5 minutes minimum) and intent protocol (IP) monitoring, the data collection process yielded 304 (search product) and 307 (experience product) responses for study 1 and study 2, respectively. Table 1 describes the sample characteristics for both studies 1 and 2, considering gender, age, education, employment, and income as respondent demographics.

Table 1 Sample Demographics

\begin{tabular}{|c|c|c|c|c|c|}
\hline \multirow[b]{2}{*}{ Measure } & \multirow[b]{2}{*}{ Item } & \multicolumn{2}{|c|}{ Study 1 (Search Products) } & \multicolumn{2}{|c|}{ Study 2 (Experience Products) } \\
\hline & & Frequency & Percentage & Frequency & Percentage \\
\hline \multirow{2}{*}{ Gender } & Male & 123 & 40.5 & 129 & 42 \\
\hline & Female & 181 & 59.5 & 178 & 58 \\
\hline \multirow{2}{*}{ Age } & Less than 20 years & 104 & 34.2 & 120 & 39.1 \\
\hline & 20 and 30 years & 133 & 43.8 & 108 & 35.2 \\
\hline
\end{tabular}




\begin{tabular}{|c|c|c|c|c|c|}
\hline & More than 30 years & 67 & 22 & 79 & 25.7 \\
\hline \multirow{3}{*}{ Education } & High school & 48 & 15.8 & 62 & 20.2 \\
\hline & College & 126 & 41.4 & 109 & 35.5 \\
\hline & University & 130 & 42.8 & 136 & 44.3 \\
\hline \multirow{5}{*}{ Employment } & Student & 71 & 23.4 & 79 & 25.7 \\
\hline & Public employee & 72 & 23.7 & 59 & 19.2 \\
\hline & Private employee & 73 & 24 & 61 & 19.9 \\
\hline & Self-employed & 51 & 16.8 & 67 & 21.8 \\
\hline & Others & 37 & 12.2 & 41 & 13.4 \\
\hline \multirow{4}{*}{ Income } & Less than RMB 4000 & 108 & 35.5 & 100 & 32.6 \\
\hline & RMB 4001 to 8000 & 91 & 29.9 & 81 & 26.4 \\
\hline & RMB 8001 to 12000 & 80 & 26.3 & 87 & 28.3 \\
\hline & Above RMB 12000 & 25 & 8.2 & 39 & 12.7 \\
\hline
\end{tabular}

\section{$5 \quad$ Analysis and results}

We employed structural equation modeling (SEM) through SmartPLS 3.2 to analyze the proposed relationships in the conceptual model (Hair et al., 2017). We selected SmartPLS for analysis because it follows the variance-based SEM approach, which is comparatively less sensitive to sample size than other applications using covariance-based SEM approaches, such as AMOS (Bhattacherjee et al., 2008). The analyses were separately carried out for study 1 and study 2; however, for comparison and better clarity, the results for both studies are presented simultaneously.

\section{$5.1 \quad$ Instrument validation}

We estimated the initial reliability and validity of instruments for both studies. At the item level, the factor loadings of each item were all above the recommended value of 0.7 (Gerbing and Anderson, 1988). At the construct level, the internal consistency (Cronbach's alpha), rho_A, and composite reliability values were well above 0.70 , thus confirming the reliability of all the constructs (Nunnally, 1978). Additionally, significant item loadings on the designated latent variables and average variance extracted were greater than 0.50 , suggesting convergent validity of the scale (Fornell and Larcker, 1981; Gerbing and Anderson, 1988). Both of these conditions are met, thus establishing convergent validity (See Table 2).

Table 2 Construct reliability and validity

\begin{tabular}{|c|c|c|c|c|c|c|c|c|}
\hline \multirow[t]{2}{*}{ Construct } & \multicolumn{4}{|c|}{ Study 1 (Search Products) } & \multicolumn{4}{|c|}{ Study 2 (Experience Products) } \\
\hline & Alpha & rho_A & $\mathrm{CR}$ & AVE & Alpha & rho_A & $\mathrm{CR}$ & AVE \\
\hline $\mathrm{CI}$ & 0.941 & 0.942 & 0.955 & 0.809 & 0.916 & 0.917 & 0.937 & 0.748 \\
\hline EM & 0.898 & 0.900 & 0.929 & 0.766 & 0.887 & 0.889 & 0.922 & 0.746 \\
\hline PA & 0.808 & 0.811 & 0.874 & 0.636 & 0.862 & 0.868 & 0.907 & 0.708 \\
\hline $\mathrm{PB}$ & 0.884 & 0.886 & 0.915 & 0.684 & 0.874 & 0.874 & 0.908 & 0.664 \\
\hline SR & 0.858 & 0.862 & 0.904 & 0.701 & 0.875 & 0.892 & 0.914 & 0.728 \\
\hline WR & 0.896 & 0.915 & 0.927 & 0.760 & 0.880 & 0.976 & 0.914 & 0.727 \\
\hline
\end{tabular}




\begin{tabular}{lllllllll}
\hline OFPI & 0.894 & 0.896 & 0.926 & 0.759 & 0.883 & 0.886 & 0.920 & 0.742 \\
ONPI & 0.901 & 0.901 & 0.931 & 0.771 & 0.872 & 0.876 & 0.912 & 0.723 \\
\hline
\end{tabular}

Note: $C I=$ channel integration, $E M=$ perceived empowerment, $P A=$ perceived assortment, $P B=$ perceived benefits, SR

$=$ showrooming, $W R=$ webrooming, $O F P I=$ offline patronage intention, $O N P I=$ online patronage intention .

We checked discriminant validity in both studies by examining factor correlations (Kline, 2010) and whether the square root of the average variance extracted (AVE) for each construct was larger than its correlation with the other constructs (Fornell and Larcker, 1981). All interconstruct correlations in the analysis for both studies were significantly higher than the correlation between any pair of constructs, confirming the discriminant validity of the scale (Table 3).

Table 3 Factor correlation coefficients and square roots of AVE

\begin{tabular}{|c|c|c|c|c|c|c|c|c|}
\hline Construct & $\mathrm{CI}$ & EM & $\mathrm{PA}$ & PB & SR & WR & OFPI & ONPI \\
\hline CI & $\begin{array}{c}0.899 \\
(0.865)\end{array}$ & 0.580 & 0.622 & 0.487 & 0.247 & 0.216 & 0.586 & 0.589 \\
\hline EM & 0.584 & $\begin{array}{c}0.875 \\
(0.864)\end{array}$ & 0.671 & 0.417 & 0.245 & 0 & 0.583 & 0.580 \\
\hline PA & 0.580 & 0.554 & $\begin{array}{c}0.797 \\
(0.842)\end{array}$ & 0.437 & 03 & 0.148 & 0.590 & 0.647 \\
\hline PB & 0.545 & 0.531 & 0.545 & $\begin{array}{c}0.827 \\
(0.815)\end{array}$ & & 0.162 & 0.573 & 0.464 \\
\hline SR & 0.490 & 0.335 & 0.364 & 0.294 & 0.837 & 0.111 & 0.241 & 0.422 \\
\hline WR & 0.337 & 0.321 & 0.255 & & 0.070 & $\begin{array}{c}0.872 \\
(0.853)\end{array}$ & 0.245 & 0.152 \\
\hline OFPI & 0.632 & 0.539 & & 0.505 & 0.233 & 0.554 & $\begin{array}{c}0.871 \\
(0.861)\end{array}$ & 0.456 \\
\hline ONPI & 0.632 & 0.610 & & 0.624 & 0.467 & 0.207 & 0.472 & $\begin{array}{c}0.878 \\
(0.850)\end{array}$ \\
\hline
\end{tabular}

Note: $C I=$ channel integration, $E M=$ empowerment, $P A=$ perceived assortment, $P B=$ perceived benefits, $S R=$ showrooming, $W R=$ webrooming, $O F P I=$ offline patronage intention, $O N P I=$ online patronage intention. The numbers on the diagonal represent the square root of the average variance extracted; the values in the parentheses are for experience products; and the below/above diagonal values are the inter-construct correlations for search/experience products. All the inter-construct correlations are significant at $p<0.001$.

The following section discusses the path model results of study 1 and study 2 .

\subsection{Study 1 (search products)}

Having established the reliability and validity of the measurement model, we next assessed the structural model using SmartPLS 3.2. We examined the direct and indirect effects of channel integration on online patronage intention (ONPI) and offline patronage intention (OFPI) through mediating variables, that is, perceived empowerment (EW), perceived assortment (PA) and perceived benefits (PB). Moreover, we measured the moderating effects of showrooming (SR) and webrooming (WR) on the pathways of CI and ONPI/OFPI. The $\mathrm{R}^{2}$ values for EM, PA, PB, OFNI, and ONFI in study 1 are $34.1 \%, 33.7 \%, 29.7 \%, 63.3 \%$, and $62.0 \%$ respectively. Table 4 presents the structural models' results for study 1 and study 2 . 
Table 4 Structural model results (direct effects)

\begin{tabular}{|c|c|c|c|c|c|c|c|c|}
\hline \multirow{3}{*}{ Relationship } & \multicolumn{4}{|c|}{ Study 1 (Search products) } & \multicolumn{4}{|c|}{ Study 2 (Experience products) } \\
\hline & \multirow[b]{2}{*}{ Estimate } & \multirow[b]{2}{*}{ T-value } & \multicolumn{2}{|c|}{$\mathrm{BCCI}$} & \multirow[b]{2}{*}{ Estimate } & \multirow[b]{2}{*}{ T-value } & \multicolumn{2}{|c|}{$\mathrm{BCCI}$} \\
\hline & & & Lower & Upper & & & Lower & Upper \\
\hline $\mathrm{CI} \rightarrow \mathrm{EM}$ & 0.584 & 12.805 & 0.482 & 0.658 & 0.580 & 13.562 & 0.481 & 0.655 \\
\hline $\mathrm{CI} \rightarrow \mathrm{PA}$ & 0.580 & 12.032 & 0.463 & 0.657 & 0.622 & 15.839 & 0.537 & 0.693 \\
\hline $\mathrm{CI} \rightarrow \mathrm{PB}$ & 0.545 & 10.993 & 0.446 & 0.634 & 0.487 & 10.706 & 0.390 & 0.569 \\
\hline $\mathrm{CI} \rightarrow$ OFPI & 0.293 & 5.907 & 0.198 & 0.389 & 0.213 & 3.844 & 0.101 & 0.320 \\
\hline $\mathrm{CI} \rightarrow$ ONPI & 0.215 & 3.675 & 0.106 & 0.327 & 0.181 & 3.193 & 0.068 & 0.278 \\
\hline $\mathrm{EM} \rightarrow$ OFPI & 0.089 & 1.789 & 0.002 & 0.184 & 0.192 & 3.553 & 0.077 & 0.283 \\
\hline $\mathrm{EM} \rightarrow$ ONPI & 0.211 & 4.259 & 0.100 & 0.302 & 0.200 & 3.817 & 0.099 & 0.298 \\
\hline $\mathrm{PA} \rightarrow$ OFPI & 0.125 & 2.809 & 0.037 & 0.212 & 0.184 & 3.270 & & 0.296 \\
\hline $\mathrm{PA} \rightarrow$ ONPI & 0.231 & 4.553 & 0.128 & 0.325 & 0.250 & 5.002 & 0.150 & 0.343 \\
\hline $\mathrm{PB} \rightarrow$ OFPI & 0.190 & 3.863 & 0.087 & 0.278 & 0.288 & 6.245 & 0.199 & 0.376 \\
\hline $\mathrm{PB} \rightarrow$ ONPI & 0.242 & 4.857 & 0.146 & 0.336 & 0.161 & 3.648 & 0.074 & 0.253 \\
\hline $\mathrm{SR} \rightarrow$ ONPI & 0.182 & 3.968 & 0.101 & 0.279 & 0.251 & 4.976 & 0.161 & 0.359 \\
\hline $\mathrm{WR} \rightarrow$ OFPI & 0.383 & 9.218 & 0.300 & 0.462 & 0.099 & 2.406 & 0.021 & 0.184 \\
\hline
\end{tabular}

The direct effects of CI on OFPI $(\beta=.293, \mathrm{t}=5.907)$ and ONPI $(\beta=.215, \mathrm{t}=3.675)$ are significant, thus confirming H1. To verify the mediating effects $(\mathrm{H} 2-\mathrm{H} 4)$, we assessed the direct and indirect effects of channel integration on ONPI and OFPI through each of the mediating variables. The indirect effects of CI on OFPI and ONPI through perceived assortment $(\mathrm{PA})(\beta=.073, \mathrm{t}=2.670 ; \beta=.134, \mathrm{t}=4$.194) and perceived benefits $(\mathrm{PF})(\beta=.104$, $\mathrm{t}=3.491 ; \beta=.132, \mathrm{t}=4.663$ ) are significant; thus, confirming $\mathrm{H} 3$ and $\mathrm{H} 4$. However, for the mediating effects of perceived empowerment $(\mathrm{EM})$, the indirect effect of CI on ONPI $(\beta=.123$, $t=4.162)$ is significant while the indirect effect of CI on OFPI $(\beta=.052, t=1.756)$ is not significant. Therefore, $\mathrm{H} 2 \mathrm{a}$ is supported while $\mathrm{H} 2 \mathrm{~b}$ is not supported. Moreover, EM has a significant direct effect on ONPI. This indicates that for search products consumers feel more empowered by online channels as they have the ability to compare prices, products, and delivery services. This provides more self-control and feelings of empowerment to consumers. Moreover, the results indicate that the effect of channel integration on ONPI is moderated by showrooming since the interaction effect of channel integration and showrooming $(\beta=.134, \mathrm{t}$ $=3.518)$ is significant. Similarly, the interaction effect of channel integration and webrooming $(\beta=.205, \mathrm{t}=8.000)$ is significant. Thus, webrooming moderates the relationship between channel integration on OFPI. Table 5 presents the specific indirect and interaction effects, while Figure 2 shows for search products the interaction effects of showrooming/webrooming on the 
relationship between channel integration and consumer patronage intention for an online/offline store.

\subsection{Study 2 (experience products)}

In study 2, we followed procedures similar to those of study 1 for instrument validation, reliability, validity, common method variance, and hypotheses testing. The $\mathrm{R}^{2}$ values for $\mathrm{EM}$, PA, PB, OFNI, and ONFI in study 2 are 33.6\%, 38.7\%, 23.7\%, 55.8\%, and 59.6\%, respectively. The path model results indicate that the direct effects of CI on OFPI $(\beta=.213, t=3.844)$ and ONPI ( $\beta=.181, \mathrm{t}=3.193)$ are significant, thus confirming H1. The indirect effects of $\mathrm{CI}$ on OFPI and ONPI through perceived empowerment $(\beta=.112, \mathrm{t}=3.348 ; \beta=.116, \mathrm{t}=3.603)$, perceived assortment $(\beta=.114, \mathrm{t}=3.333 ; \beta=.156, \mathrm{t}=4.619)$, and perceived benefits $(\beta=.140$, $\mathrm{t}=5.735 ; \beta=.078, \mathrm{t}=3.433)$ are significant. Therefore, perceived empowerment, perceived assortment, and perceived benefits mediate the relationships between CI and OFPI/ ONPI, thus confirming $\mathrm{H} 2, \mathrm{H} 3$, and $\mathrm{H} 4$. Moreover, results indicate that the interaction effect of showrooming and CI on ONPI $(\beta=.206, t=4.733)$ and the interaction effect of webrooming and CI on OFPI $(\beta=.149, \mathrm{t}=3.653)$ are significant. Therefore, the impacts of CI on OFPI/ ONPI are subject to consumer showrooming and webrooming behaviors (Table 5, Figure 3).

Table 5 Specific indirect and moderating effects

\begin{tabular}{|c|c|c|c|c|c|c|c|c|c|}
\hline \multirow{3}{*}{ Effect Type } & \multirow{3}{*}{ Relationship } & \multicolumn{4}{|c|}{ Study 1 (Search products) } & \multicolumn{4}{|c|}{ Study 2 (Experience products) } \\
\hline & & \multirow[t]{2}{*}{ Estimate } & \multirow[t]{2}{*}{ T-values } & \multicolumn{2}{|c|}{$\mathrm{BCCI}$} & \multirow[t]{2}{*}{ Estimate } & \multirow[t]{2}{*}{ T-values } & \multicolumn{2}{|c|}{$\mathrm{BCCI}$} \\
\hline & & & & Lower & Upper & & & Lower & Upper \\
\hline \multirow{5}{*}{ Indirect effects } & $\mathrm{CI} \rightarrow \mathrm{EM} \rightarrow \mathrm{OFPI}$ & 0.052 & 1.756 & -0.001 & 0.110 & 0.112 & 3.348 & 0.041 & 0.172 \\
\hline & $\mathrm{CI} \rightarrow \mathrm{PA} \rightarrow \mathrm{OFPI}$ & 0.073 & 2.670 & 0.021 & 0.131 & 0.114 & 3.333 & 0.047 & 0.188 \\
\hline & $\mathrm{CI} \rightarrow \mathrm{PB} \rightarrow \mathrm{OFPI}$ & 0.104 & 3.491 & 0.045 & 0.162 & 0.140 & 5.735 & 0.093 & 0.196 \\
\hline & $\mathrm{CI} \rightarrow \mathrm{EM} \rightarrow \mathrm{ONPI}$ & 0.123 & 4.162 & 0.059 & 0.180 & 0.116 & 3.603 & 0.056 & 0.180 \\
\hline & $\mathrm{CI} \rightarrow \mathrm{PA} \rightarrow \mathrm{ONPI}$ & 0.134 & 4.194 & 0.074 & 0.201 & 0.156 & 4.619 & 0.093 & 0.223 \\
\hline \multirow{3}{*}{$\begin{array}{l}\text { Moderating } \\
\text { effects }\end{array}$} & $\mathrm{CI} \rightarrow \mathrm{PB} \rightarrow \mathrm{ONPI}$ & 0.132 & 4.663 & 0.083 & 0.188 & 0.078 & 3.433 & 0.038 & 0.128 \\
\hline & $\mathrm{CI} * \mathrm{SR} \rightarrow \mathrm{ONPI}$ & 0.134 & 3.518 & 0.063 & 0.204 & 0.206 & 4.733 & 0.106 & 0.277 \\
\hline & $\mathrm{CI} * \mathrm{WR} \rightarrow \mathrm{OFPI}$ & 0.205 & 8.000 & 0.150 & 0.251 & 0.149 & 3.653 & 0.060 & 0.212 \\
\hline
\end{tabular}



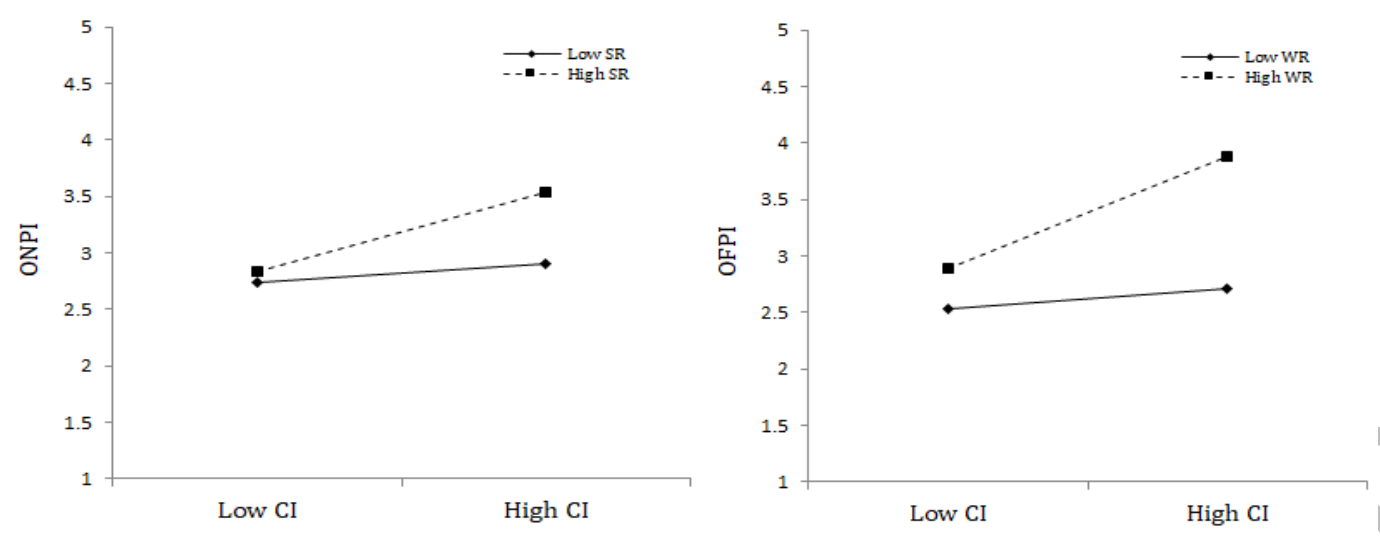

Figure 2 Moderating effects of showrooming and webrooming for search products
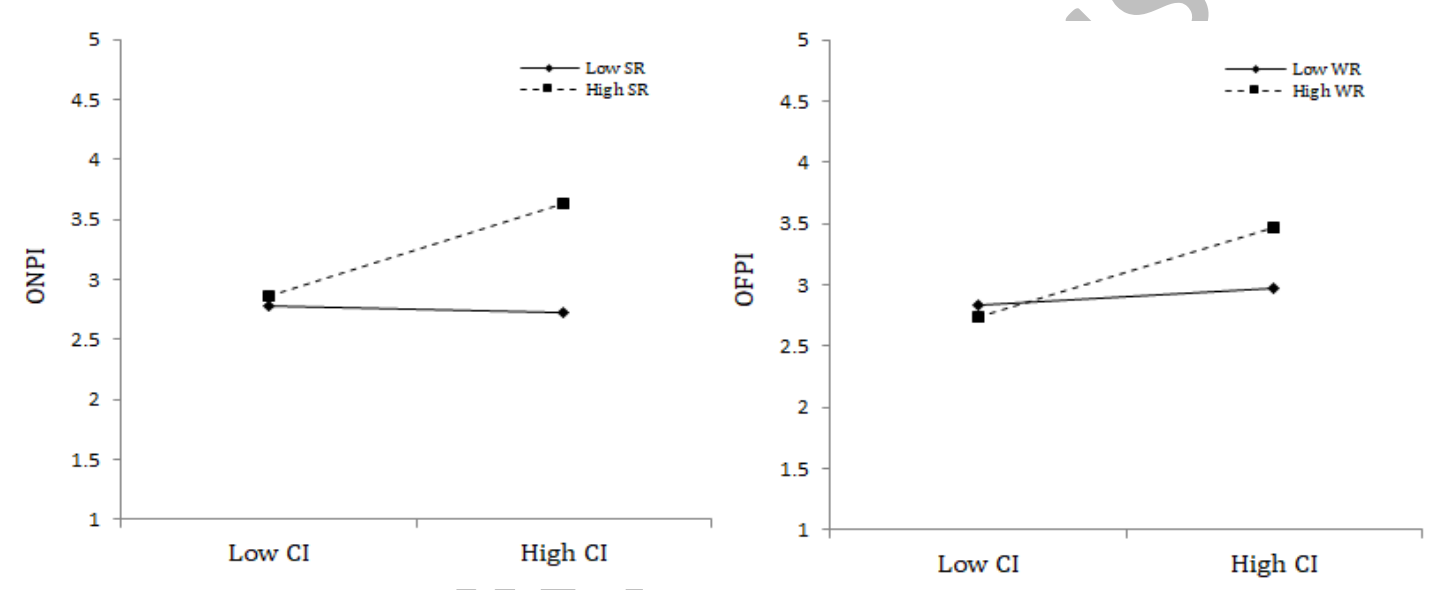

Figure 3 Moderating effects of showrooming and webrooming for experience products

\section{Discussion and conclusion}

Based on the objective to envision the merits of channel integration amid different product characteristics and consumer shopping considerations, this research offers new insights into consumer patronage intentions. Through a robust conceptual model, we proposed that consumers' cross-channel free-riding behaviors (showrooming and webrooming) vary based on different product characteristics. Moreover, we exemplify the intervening effects of empowerment, assortment, and benefits in translating consumer patronage for offline and online stores.

The results of the two studies are drawn with the help of variance-based SEM, which provides significant support for the proposed conceptual model. Both studies confirm the positive effect of channel integration on consumers' offline and online patronage intention. This suggests that, irrespective of the product characteristics, consumer perception of channel integration 
influences their patronage intention for online and offline stores. These findings are consistent with those of Emrich et al. (2015). The empirical findings of this study also reaffirm consumers' positive intention of shopping over integrated channels in current times (Zhang et al., 2018). The findings of Zhang et el. (2018) presented the patronage intentions of consumers over integrated channel settings; however, the results of our study extend his work by providing elucidations to the bifurcated patronage intentions of consumers; that is, online/offline patronage. The results not only provide clarification with respect to product characteristics, they also reaffirm consumers' decision making to shop over integrated channels. Furthermore, the results also complement past studies which predict that in an Omni-channel environment, retailers' integrated channels denote their value in facilitating consumers amid different product characteristics (Herhausen et al., 2015; Saghiri et al., 2017).

The varied results concerning mediating effects of perceived empowerment in both of the studies offer opposing and complementing findings compared to past studies. In the case of experience products, results of this study complement the findings of Emrich et al. (2015), Zhang et al. (2018), and Cao and Li (2015). Integrated channel retailers pay close attention to consumers when addressing their needs and try to empower them as they shop in both online and offline channels. For example, upon experiencing integrated products and services across online and offline channels, consumers are no longer bound to shop from one channel; instead, they select the channel that offers additional benefits, such as product assortment or empowerment. Similarly, when consumers do not experience boundaries between online and offline channels, they feel more liberty in their shopping iterations. Contrary to the findings of experience products, in the case of search products, we note that empowerment has a significant mediating effect on the CI-ONPI relationship; however, we do not find any significant effect of empowerment on the CI-OFPI relationship. This implies that users' perceived empowerment may vary for different products and channels.

Moreover, our results confirm a significant mediating role of perceived benefits on CI-ONPI and CN-OFPI relationships. This implies that the perceived benefits of channel integration, such as easy and quick availability of the products with comparatively less time and effort, play an important role in forming user patronage intentions over integrated channels. In line with past literature (Emrich et al., 2015), our findings confirm that perceived shopping benefits have a considerable effect on channel integration and consumers' online and offline patronage intentions. The structures of perceived benefits and assortment resonate more with consumer behavioral intentions over integrated channels. For both experience and search products, the integrated channels can address consumer perceptions of the variety offered by the retailers. 
While the online channel can display more variety, there is generally a limitation to product display in the offline channel, thus revealing the value of channel integration in terms of variety. The issue of variety addresses the inception of integrated channels, and the convenience of shopping also resonates with the behavioral intentions of consumers upon providing the convenience of comparing prices, the convenience of delivering products, time savings, and shopping at any time. Integrated channels also reduce the risk perception of consumers. Over retailers' integrated channels, consumers can experience product quality in the offline store and then can compare price and availability over the online channel, thus increasing their confidence, satisfaction, and patronage towards integrated channels. These findings complement those of Zhu et al. (2018) and Bertrandie and Zielke (2017).

In both studies, the showrooming and webrooming results suggest that it is a common norm among consumers to engage in such behaviors on integrated channels. Moreover, retailers nowadays are facilitating consumers' cross-channel free-riding behavior by providing integrated shopping avenues (Zhu et al., 2018). The results for both studies affirm that, for search and experience products, being consistent important in the case of showrooming. From a high-level perspective of showrooming, greater channel integration significantly improves consumer intention to patronage online stores. On the other hand, the effect of channel integration on offline patronage intention is consistent in a low webrooming scenario, while in a high webrooming scenario, an increase in the level of channel integration significantly improves consumers' offline patronage intention. Moreover, product assortment across channels may encourage consumers to engage in webrooming or showrooming behaviors and thus improve consumer visits to online and offline stores. For example, showrooming may encourage users to visit retailers' online channels and thus result in patronage. Similarly, webrooming may lead consumers to the offline stores and, eventually, to their patronage intention for such stores. Thus, both webrooming and showrooming may help retailers in indirect revenue contribution through developing consumer online or offline patronage intentions.

\subsection{Theoretical implications}

This research offers some theoretical implications. First, we highlight consumer shopping considerations in an integrated channel setting. As contemporary retailers are initiating an omni-channel strategy for creating effectiveness in their business models, integrated channels are yielding more positive results for them. The results show that consumers desire to control their choices in the shape of empowerment and perceive more shopping benefits over an integrated channel, both of which generate more consumer patronage. 
Second, this study exemplifies the self-determination theory by considering empowerment, assortment structure, and integrated channel benefits as intervening constructs. By considering these intervening constructs, this research explores consumers' needs and intrinsic motivation for shopping over an integrated channel. Empirical results mostly confirm the mediating effects, thus enriching the literature on integrated channel retailing. In the case of search products, consumers do not feel empowered in offline stores, thus prompting academicians to underpin other intervening constructs to identify consumer patronage for offline stores when shopping for search products.

Third and lastly, findings herein reveal that consumer cross-channel switching behavior strengthens the integrated channel settings for both consumer online and offline patronage for retailers' stores. Nevertheless, the results also suggest novel insights from the perspective of integrated channel efficacy, as consumers' free cross-channel free-riding behavior (showrooming and webrooming) reduces their liberty concern and facilitates their channel freeriding behavior.

Lastly, this study also reaffirms the theoretical approach instigated in the theory of selfdetermination; that is, the integrated channels of retailers give the affiliation of shopping achievement, product knowledge, and the shopping skills required by consumers for shopping over integrated channels. Consumer perceptions of autonomy also reaffirm the retailer's competence which is dispensed over its integrated channels to let consumers master their shopping tasks and enjoy a seamless shopping journey. Consumer autonomy and competence provide positive shopping vibes to shop over integrated channels, which then develop a sense of belongingness and connectedness among consumers in the shape of buying intentions from their selected channels, that is, online or offline.

\subsection{Managerial implications}

This study has some implications for retail managers. We present our findings on integrated channel retailers as follows. 1) Integrated channel retailers have invested immense resources into retaining consumers. Such investments may not render sustained customer patronage, unless retailers address consumers' desire for getting control of their shopping iterations. This may be achieved by empowering consumers' perceived shopping benefits; that is, transaction control, shopping at any time without having to be present at an offline store, abolishing confusion over product assortment structures, and addressing integrated shopping benefits, such as convenience, variety, and risk. 2) Retailers may provide in-store online terminals to limit consumer intention to look for alternatives elsewhere. Similarly, retailers can enrich their 
online stores with offline store activities, thus bridging showrooming and webrooming over an integrated channel framework. Such facilitation strengthens the value of the integrated channel and can resonate more patronage among consumers. The study also suggests that retailers integrate their channels in order to increase the shopping efficacy of goal-directed consumers who particularly look for varied benefits and self-control perspectives. Channel integration through digitization strategies allows consumers to save time and effort in gathering product information at the online store, whereas the physical store offers them immediate possession of products. In this way, the retailers will retain free-riding consumers by satisfying their expectations. Moreover, the retailers can plug in augmented reality software suites over their online and offline stores, which will excite consumers to shop over integrated shopping environments. Not only does it excite consumers, it also provides consumers with valuable choices among visuals, especially when shopping for apparel. Furthermore, it also provides a sense of control to consumers during their shopping expedition.

\subsection{Limitations and future research}

This study addresses the merits of channel integration, but there are still a few limitations to consider. First, although we have incorporated only online and offline channels of integrated retailers, we cannot claim to have captured the full view of integrated channels. Future studies may consider other integrated channels as well, such as mobile devices, consumer touchpoints (i.e., brand advertisements), in-store communication, and peer-to-peer communication, which can provide more promising results from the perspective of patronage intentions. Second, we cannot deny the existence of other intervening and moderating factors, such as the roles that gender, online/offline store environment, consumer personality traits, or other critical factors, have when measuring patronage. Third, although common method bias is not a serious issue in this study, cross-sectional survey designs may suffer from it. Therefore, for generalizability, other research designs, such as longitudinal or experimental, are recommended. Fourth, this study measures consumer patronage intentions for online and offline stores and not their actual behaviors, and so generalizations should be made with caution. Fifth and finally, this study is based on Chinese consumers. Other geographical consumers may have varied perceptions about integrated channels, and thus the results herein may not be generalizable for all consumers/retailers.

\section{$7 \quad$ References}

Arora, S., Sahney, S., 2018. Consumer's webrooming conduct: an explanation using the theory of planned behavior. Asia Pacific J. Mark. Logist. 30, 1040-1063. 
https://doi.org/10.1108/APJML-08-2017-0185

Baal, S. Van, 2014. Should retailers harmonize marketing variables across their distribution channels? An investigation of cross-channel effects in multi-channel retailing. J. Retail. Consum. Serv. 21, 1038-1046. https://doi.org/10.1016/j.jretconser.2014.04.012

Baal, S. van, Dach, C., 2005. Free riding and customer retention across retailers' channels. J. Interact. Mark. 19, 75-85. https://doi.org/10.1002/DIR.20036

Bang, Y., Lee, D.-J., Han, K., Hwang, M., Ahn, J.-H., 2013. Channel Capabilities, Product Characteristics, and the Impacts of Mobile Channel Introduction. J. Manag. Inf, Syst. 30, 101-126. https://doi.org/10.2753/MIS0742-1222300204

Bendoly, E., Blocher, J.D., Bretthauer, K.M., Krishnan, S., Venkataramanan, M.A., 2005. Online/In-Store Integration and Customer Retention. J. Serv. Res. 7, 313-327. https://doi.org/10.1177/1094670504273964

Berthiaume, D., 2019. Survey: Webrooming, showrooming popular with shoppers | Chain Store Age [WWW Document].

Bertrandie, L., Zielke, S., 2017. The effects of multi-channel assortment integration on customer confusion. Int. Rev. Retail. Distrib. Consum. Res. 27, 437-449. https://doi.org/10.1080/09593969.2017.1383292

Bhattacherjee, A., Perols, J., Sanford, C., 2008. Information Technology Continuance: A Theoretic Extension and Empirical Test information technology continuance : a theoretic extension and empirical test. J. Comput. Inf. Syst. 49, 17-26. https://doi.org/10.1080/08874417.2008.11645302

Blut, M., Teller, C., Floh, A., 2018. Testing Retail Marketing-Mix Effects on Patronage: A Meta-Analysis. J. Retail. 94, 113-135. https://doi.org/10.1016/J.JRETAI.2018.03.001

Broniarczyk, S.M., Griffin, J.G., 2014. Decision Difficulty in the Age of Consumer Empowerment. J. Consum. Psychol. https://doi.org/10.1016/j.jcps.2014.05.003

Cao, L., Li, L., 2015. The Impact of Cross-Channel Integration on Retailers' Sales Growth. J. Retail. 91, 198-216. https://doi.org/10.1016/j.jretai.2014.12.005

Cattaneo, L.B., Chapman, A.R., 2010. The process of empowerment: A model for use in research and practice. Am. Psychol. 65, 646-659. https://doi.org/10.1037/a0018854

Cummins, S., Peltier, J.W., Dixon, A., 2016. Omni-channel research framework in the context of personal selling and sales management. J. Res. Interact. Mark. 10, 2-16. https://doi.org/10.1108/JRIM-12-2015-0094

Emrich, O., Paul, M., Rudolph, T., 2015. Shopping Benefits of Multichannel Assortment Integration and the Moderating Role of Retailer Type. J. Retail. 91, 326-342. 
https://doi.org/10.1016/j.jretai.2014.12.003

Esposito, G., van Bavel, R., Baranowski, T., Duch-Brown, N., 2016. Applying the Model of Goal-Directed Behavior, Including Descriptive Norms, to Physical Activity Intentions. Psychol. Rep. 119, 5-26. https://doi.org/10.1177/0033294116649576

Fernández, N.V., Pérez, M.J.S., Vázquez-Casielles, R., 2018. Webroomers versus showroomers: Are they the same? J. Bus. Res. 92, 300-320. https://doi.org/10.1016/j.jbusres.2018.08.004

Fevad, 2017. Les chiffres clés 2016-2017.

Flavián, C., Gurrea, R., Orús, C., 2019. Combining channels to make smart purchases: The role of webrooming and showrooming. J. Retail. Consum. Serv. 52, 101923. https://doi.org/10.1016/j.jretconser.2019.101923

Flavián, C., Gurrea, R., Orús, C., 2016. Choice confidence in the webrooming purchase process: The impact of online positive reviews and the motivation to touch. J. Consum. Behav. 15, 459-476. https://doi.org/10.1002/cb.1585

Fornell, C., Larcker, D., 1981. Evaluating Structural Equation Models with Unobservable Variables and Measurement Error. J. Mark. Res. 18, 50, 39.

Frasquet, M., Mollá, A., Ruiz, E., 2015. Identifying patterns in channel usage across the search, purchase and post-sales stages of shopping. Electron. Commer. Res. Appl. 14, 654-665. https://doi.org/10.1016/J.ELERAP.2015.10.002

Gallino, S., Moreno, A., 2014. Integration of Online and Offline Channels in Retail: The Impact of Sharing Reliable Inventory Availability Information. Manage. Sci. 60, 1434-1451. https://doi.org/10.1287/mnsc.2014.1951

Gao, F., Su, X., 2017. Omnichannel retail operations with buy-online-and-pick-up-in-store. Manage. Sci. 63, 2478-2492. https://doi.org/10.1287/mnsc.2016.2473

Gensler, S., Neslin, S.A., Verhoef, P.C., 2017. The Showrooming Phenomenon: It's More than Just About Price. J. Interact. Mark. 38, 29-43. https://doi.org/10.1016/j.intmar.2017.01.003

Gerbing, D.W., Anderson, J.C., 1988. An Updated Paradigm for Scale Development Incorporating Unidimensionality and Its Assessment. J. Mark. Res. 25, 186. https://doi.org/10.2307/3172650

Glushko, R.J., Tabas, L., 2009. Designing service systems by bridging the "front stage" and “back stage.” Inf. Syst. E-bus. Manag. 7, 407-427. https://doi.org/10.1007/s10257-0080106-0

Hair, J.J.F., Hult, G.T.M., Ringle, C., Sarstedt, M., 2016. A primer on partial least squares 
structural equation modeling (PLS-SEM), 2nd Ed. ed. Sage Publications, Los Angeles: Sage.

Heitz-Spahn, S., 2013. Cross-channel free-riding consumer behavior in a multichannel environment: An investigation of shopping motives, sociodemographics and product categories. J. Retail. Consum. Serv. 20. https://doi.org/10.1016/j.jretconser.2013.07.006

Herhausen, D., Binder, J., Schoegel, M., Herrmann, A., 2015. Integrating Bricks with Clicks: Retailer-Level and Channel-Level Outcomes of Online-Offline Channel Integration. J. Retail. 91, 309-325. https://doi.org/10.1016/j.jretai.2014.12.009

Hossain, T.M.T., Akter, S., Kattiyapornpong, U., Dwivedi, Y.K., 2019. Multichannel integration quality: A systematic review and agenda for future research. J. Retail. Consum. Serv. 49, 154-163. https://doi.org/10.1016/J.JRETCONSER.2019.03.019

$\mathrm{Hu}, \mathrm{H}$. , Research, A.K.-J. of B., 2019, U., 2019. When is enough, enough? Investigating product reviews and information overload from a consumer empowerment perspective. J. Bus. Res. 100, 27-37.

Kacen, J.J., Hess, J.D., Kevin Chiang, W.-Y., 2013. Bricks or Clicks? Consumer Attitudes toward Traditional Stores and Online Stores. Glob. Econ. Manag. Rev. 18, 12-21. https://doi.org/10.1016/S2340-1540(13)70003-3

Kahn, B.E., Wansink, B., 2004. The Influence of Assortment Structure on Perceived Variety and Consumption Quantities. J. Consum. Res. 30, 519-533. https://doi.org/10.1086/380286

Kang, J.Y.M., 2018. Showrooming, Webrooming, and User-Generated Content Creation in the Omnichannel Era. J. Internet Commer. 17, 145-169. https://doi.org/10.1080/15332861.2018.1433907

Kline, R.B., 2010. Principles and Practice of Structural Equation Modeling, Third Edit. ed. The Guilford Press.

Krueger, J., 2015. Omnichannel shoppers: An emerging retail reality [WWW Document]. Thinkwithgoogle. URL https://www.thinkwithgoogle.com/marketingresources/omnichannel/omni-channel-shoppers-an-emerging-retail-reality/

Lee, Z.W.Y., Chan, T.K.H., Chong, A.Y.L., Thadani, D.R., 2019. Customer engagement through omnichannel retailing: The effects of channel integration quality. Ind. Mark. Manag. 77, 90-101. https://doi.org/10.1016/j.indmarman.2018.12.004

Li, M., Jiang, Z. (Jack), Fan, Z., Hou, J., 2017. Expert or peer? Understanding the implications of virtual advisor identity on emergency rescuer empowerment in mobile psychological self-help services. Inf. Manag. 54, 866-886. https://doi.org/10.1016/j.im.2017.01.002 
Li, Y., Liu, H., Limb, E.T.K., Goh, J.M., Yang, F., Lee, M.K.O., 2018. Customer's reaction to cross-channel integration in omnichannel retailing: The mediating roles of retailer uncertainty, identity attractiveness, and switching costs. Decis. Support Syst. 109, 50-60.

Melis, K., Campo, K., Breugelmans, E., Lamey, L., 2015. The Impact of the Multi-channel Retail Mix on Online Store Choice: Does Online Experience Matter? J. Retail. 91, 272288. https://doi.org/10.1016/j.jretai.2014.12.004

Neslin, S.A., 2009. Key Issues in Multichannel Customer Management: Current Knowledge and Future Directions. J. Interact. Mark. 23, 20-81. https://doi.org/10.1016/J.INTMAR.2008.10.005

Nunnally, J.C., 1978. Psychometric Theory, 2nd ed. Mcgraw-Hill College, New York.

Ofek, E., Katona, Z., Sarvary, M., 2011. "Bricks and Clicks": The Impact of Product Returns on the Strategies of Multichannel Retailers. Mark. Sci. 30, 42-60. https://doi.org/10.1287/mksc. 1100.0588

Oh, L.-B., Teo, H.-H., Sambamurthy, V., 2012. The effects of retail channel integration through the use of information technologies on firm performance. J. Oper. Manag. 30, 368-381. https://doi.org/10.1016/J.JOM.2012.03.001

Patrício, L., Fisk, R.P., Falcão e Cunha, J., 2008. Designing Multi-Interface Service Experiences. J. Serv. Res. 10, 318-334. https://doi.org/10.1177/1094670508314264

Pauwels, K., Neslin, S.A., 2015. Building With Bricks and Mortar: The Revenue Impact of Opening Physical Stores in a Multichannel Environment. J. Retail. 91, 182-197. https://doi.org/10.1016/j.jretai.2015.02.001

Rapp, A., Baker, T.L., Bachrach, D.G., Ogilvie, J., Beitelspacher, L.S., 2015. Perceived customer showrooming behavior and the effect on retail salesperson self-efficacy and performance. J. Retail. 91, 358-369. https://doi.org/10.1016/j.jretai.2014.12.007

Reid, L.F., Ross, H.F., Vignali, G., 2016. An exploration of the relationship between product selection criteria and engagement with "show-rooming" and "web-rooming" in the consumer's decision-making process. Int. J. Bus. Glob. 17, 364-383. https://doi.org/10.1504/IJBG.2016.078851

Rubio, N., Villaseñor, N., Yagüe, M.J., 2017. Creation of consumer loyalty and trust in the retailer through store brands: The moderating effect of choice of store brand name. J. Retail. Consum. Serv. 34, 358-368. https://doi.org/10.1016/j.jretconser.2016.07.014

Saghiri, S., Wilding, R., Mena, C., Bourlakis, M., 2017. Toward a three-dimensional framework for omni-channel. J. Bus. Res. 77, 53-67. https://doi.org/10.1016/J.JBUSRES.2017.03.025 
Schröder, H., Zaharia, S., 2008. Linking multi-channel customer behavior with shopping motives: An empirical investigation of a German retailer. J. Retail. Consum. Serv. 15, 452-468. https://doi.org/10.1016/J.JRETCONSER.2008.01.001

Shankar, A., Cherrier, H., Canniford, R., 2006. Consumer empowerment: A Foucauldian interpretation. Eur. J. Mark. 40, 1013-1030. https://doi.org/10.1108/03090560610680989

Shareef, M.A., Kumar, V., Kumar, U., Dwivedi, Y.K., 2011. E-Government Adoption Model (GAM): Differing service maturity levels. Gov. Inf. Q. 28, 17-35. https://doi.org/10.1016/j.giq.2010.05.006

Shareef, M.A., Mukerji, B., Alryalat, M.A.A., Wright, A., Dwivedi, Y.K., 2018. Advertisements on Facebook: Identifying the persuasive elements in the development of positive attitudes in consumers. J. Retail. Consum. Serv. 43, 258-268. https://doi.org/10.1016/j.jretconser.2018.04.006

Shareef, M.A., Mukerji, B., Dwivedi, Y.K., Rana, N.P., Islam, R., 2019. Social media marketing: Comparative effect of advertisement sources. J. Retail. Consum. Serv. 46, 5869. https://doi.org/10.1016/J.JRETCONSER.2017.11.001

Shi, B., Liu, J., 2018. Showrooming phenomenon - A grounded theory investigation of the showrooming phenomenon via a customer's lens.

Singh, S., Ratchford, B.T., Prasad, A., 2014. Offline and online search in used durables markets. J. Retail. 90, 301-320. https://doi.org/10.1016/j.jretai.2014.03.005

Tagashira, T., Minami, C., 2019. The Effect of Cross-Channel Integration on Cost Efficiency. J. Interact. Mark. 47, 68-83. https://doi.org/10.1016/j.intmar.2019.03.002

Verhoef, P.C., Kannan, P.K., Inman, J.J., 2015. From Multi-Channel Retailing to OmniChannel Retailing. Introduction to the Special Issue on Multi-Channel Retailing. J. Retail. 91, 174-181. https://doi.org/10.1016/j.jretai.2015.02.005

Wang, R.J.H., Malthouse, E.C., Krishnamurthi, L., 2015. On the Go: How Mobile Shopping Affects Customer Purchase Behavior. J. Retail. 91, 217-234. https://doi.org/10.1016/j.jretai.2015.01.002

Wathieu, L., Brenner, L., Carmon, Z., Chattopadhyay, A., Wertenbroch, K., Drolet, A., Gourville, J., Muthukrishnan, A. V., Novemsky, N., Ratner, R.K., Wu, G., 2002. Consumer Control and Empowerment: A Primer. Mark. Lett. 13, 297-305. https://doi.org/10.1023/A:1020311914022

Wolny, J., Charoensuksai, N., 2014. Mapping customer journeys in multichannel decisionmaking. J. Direct, Data Digit. Mark. Pract. 15, 317-326. https://doi.org/10.1057/dddmp.2014.24 
Yadav, M.S., Pavlou, P.A., Berry, L., Hoffman, D., Shankar, V., Singh, J., Sorescu, A., SriniVasan, R., Varadarajan, R., 2014. Marketing in Computer-Mediated Environments: Research Synthesis and New Directions. J. Mark. 78, 1547-7185.

Zhang, M., Ren, C., Wang, G.A., He, Z., 2018. The impact of channel integration on consumer responses in omni-channel retailing: The mediating effect of consumer empowerment. Electron. Commer. Res. Appl. 28, 181-193. https://doi.org/10.1016/j.elerap.2018.02.002

Zhu, J., Goraya, M., Cai, Y., Zhu, J., Goraya, M.A.S., Cai, Y., 2018. Retailer-Consumer Sustainable Business Environment: How Consumers' Perceived Benefits Are Translated by the Addition of New Retail Channels. Sustainability 10, 1-22. https://doi.org/10.3390/SU10092959

\section{Appendix 1: Constructs and measurement items}

\begin{tabular}{|c|c|c|}
\hline \multirow[t]{2}{*}{ Constructs with items } & \multicolumn{2}{|c|}{ Factor Loadings } \\
\hline & $\begin{array}{c}\text { Search } \\
\text { Products }\end{array}$ & $\begin{array}{l}\text { Experience } \\
\text { products }\end{array}$ \\
\hline \multicolumn{3}{|l|}{ Channel Integration [Zhang et al. (2018)] } \\
\hline $\begin{array}{l}\text { I can find consistent brand promotions and advertisements in the } \\
\text { retailer's physical store and Website. }\end{array}$ & 0.912 & 0.889 \\
\hline $\begin{array}{l}\text { I can find consistency among products and price in retailer's } \\
\text { physical store and Website. }\end{array}$ & 0.924 & 0.881 \\
\hline $\begin{array}{l}\text { I can search for products and inventory status in the retailer's } \\
\text { physical store through its Website. }\end{array}$ & 0.889 & 0.883 \\
\hline $\begin{array}{l}\text { I can redeem the retailer's gift coupons or vouchers in its physical } \\
\text { store or on the Website. }\end{array}$ & 0.900 & 0.815 \\
\hline $\begin{array}{l}\text { I can collect, return, repair, or exchange the products purchased } \\
\text { online in the retailer's physical store. }\end{array}$ & 0.870 & 0.856 \\
\hline \multicolumn{3}{|l|}{ Showrooming [Rapp et al. (2015)] } \\
\hline \multicolumn{3}{|l|}{ When I am in retailer's physical store: } \\
\hline $\begin{array}{l}\text { I search/view products in the physical store and then purchase } \\
\text { products online. }\end{array}$ & 0.842 & 0.879 \\
\hline - I often browse online channels to investigate similar products. & 0.850 & 0.872 \\
\hline - I use a mobile device to compare prices of products online. & 0.850 & 0.884 \\
\hline - I use a mobile internet device while shopping in the physical store. & 0.807 & 0.773 \\
\hline \multicolumn{3}{|l|}{ Webrooming [Rapp et al. (2015)] } \\
\hline \multicolumn{3}{|l|}{ While I am going to purchase product from retailers' online store: } \\
\hline $\begin{array}{l}\text { I search/view products online via mobile and then purchase } \\
\text { products in the physical store. }\end{array}$ & 0.859 & 0.869 \\
\hline $\begin{array}{l}\text { - I often visit online channels for products and examine product } \\
\text { characteristics at physical store. }\end{array}$ & 0.908 & 0.815 \\
\hline $\begin{array}{l}\text { On the retailers' online store, I check the availability of products at } \\
\text { the physical store and make a purchase at physical store. }\end{array}$ & 0.882 & 0.905 \\
\hline $\begin{array}{l}\text { I use a mobile internet device to fetch information about } \\
\text { discount/promotion offers at physical stores. }\end{array}$ & 0.838 & 0.819 \\
\hline
\end{tabular}




\begin{tabular}{|c|c|c|}
\hline Perceived Empowerment [Zhang et al. (2018)] & & \\
\hline \multicolumn{3}{|l|}{ On retailers'integrated channel: } \\
\hline - In my dealings with retailer, I feel I am in control. & 0.865 & 0.870 \\
\hline $\begin{array}{l}\text { I feel more empowered while selecting products and services from } \\
\text { both channels simultaneously. }\end{array}$ & 0.875 & 0.884 \\
\hline $\begin{array}{l}\text { During the shopping process, I can select product and service freely } \\
\text { over channels. }\end{array}$ & 0.888 & 0.865 \\
\hline $\begin{array}{l}\text { My leverage of buying products and services from different } \\
\text { channels has increased relative to the past. }\end{array}$ & 0.874 & 0.835 \\
\hline \multicolumn{3}{|l|}{$\begin{array}{l}\text { Perceived Assortment [Kahn and Wansink (2004); Emrich, Paul, } \\
\text { and Rudolph (2015)] }\end{array}$} \\
\hline On retailers' integrated channel: & & \\
\hline - The assortments offer various price ranges to choose from. & 0.805 & 0.830 \\
\hline - The assortments offer many related products. & 0.803 & 0.871 \\
\hline $\begin{array}{l}\text { - The assortments offer a variety of different quality ranges to choose } \\
\text { from. }\end{array}$ & 0.849 & 0.873 \\
\hline - The presentation of assortment products is logically arranged. & 0.728 & 0.790 \\
\hline \multicolumn{3}{|l|}{ Perceived Benefits [Shareef et al. (2018)] } \\
\hline \multicolumn{3}{|l|}{ On retailers' integrated channel: } \\
\hline - I can choose products more easily and quickly. & 0.822 & 0.787 \\
\hline - I can more easily find the product I want to buy. & 0.859 & 0.824 \\
\hline I spend less time and effort when choosing products. & 0.821 & 0.807 \\
\hline - It is easy to do online shopping at any time convenient for me. & 0.824 & 0.844 \\
\hline - The quality of decision-making is improved. & 0.809 & 0.813 \\
\hline \multicolumn{3}{|l|}{ Online Patronage Intention [Emrich, Paul, and Rudolph (2015)] } \\
\hline $\begin{array}{l}\text { I would recommend the online store of retailer to someone who } \\
\text { seeks my choice. }\end{array}$ & 0.854 & 0.833 \\
\hline $\begin{array}{l}\text { I would consider retailers' online store as my first choice in the } \\
\text { future. }\end{array}$ & 0.899 & 0.895 \\
\hline $\begin{array}{l}\text { I would encourage friends and relatives to purchase from retailers' } \\
\text { online store. }\end{array}$ & 0.868 & 0.827 \\
\hline - I would say positive things about retailers' online store. & 0.891 & 0.845 \\
\hline \multicolumn{3}{|l|}{ Offline Patronage Intention [Emrich, Paul, and Rudolph (2015)] } \\
\hline $\begin{array}{l}\text { - I would recommend the offline store of retailer to someone who } \\
\text { seeks my advice. }\end{array}$ & 0.867 & 0.778 \\
\hline $\begin{array}{l}\text { - I would consider retailers' offline store as my first choice in the } \\
\text { future. }\end{array}$ & 0.893 & 0.887 \\
\hline $\begin{array}{l}\text { I would encourage friends and relatives to purchase from retailers' } \\
\text { offline store. }\end{array}$ & 0.869 & 0.871 \\
\hline - I would say positive things about retailers' offline store. & 0.854 & 0.904 \\
\hline
\end{tabular}

